\title{
Budget request tackles habitat changes
}

\section{US wildlife agency bids to revitalize research with focus on effects of global warming.}

The US Fish and Wildlife Service (FWS) is looking to get back on its research feet, in the wake of revelations in recent years that a top official manipulated scientific results involving endangered species. A budget request now wending its way through Congress could provide an 11-14\% budget increase, including beefed-up funding to investigate how species will be affected by climate change.

There's "no question" that the agency needs more resources, says John Eadie, a wildlife biologist at the University of California, Davis. "Particularly with climate change, there's so much uncertainty," he says. "It's a huge science undertaking."

The agency has requested $\$ 10$ million to establish eight new 'landscape conservation cooperatives' across the country that would identify key locations for species protection and develop management strategies. Another $\$ 10$ million would fund research, both at the FWS and other agencies and universities, to assess the effects of climate change on wildlife populations and habitats.

Strong science support will be necessary to defend management decisions that could be taken to court, says Dan Ashe, science adviser to the agency's director. For instance, the FWS must issue a critical-habitat decision by 30 June 2010 for the polar bear, listed last year as threatened, and create a recovery plan for it. "Those are going to be very controversial documents," says Ashe. The state of Alaska sued the agency in an attempt to overturn the decision, three months after the polar bear was listed.

The agency maintains recovery plans for more than 1,000 species listed under the Endangered Species Act, and many of those will need to be updated to address the issue of climate change, says Nancy Green in Arlington, Virginia, a scientist with the FWS's endangered-

species programme. The agency is prioritizing which plans to update first, says Ashe.

The 2010 budget request for the Department of the Interior, which includes the \$1.6-billion FWS, passed the Senate appropriations committee on 25 June and a House of Representatives vote on 26 June. The requested Interior increase of $\$ 4.7$ billion over 2009 levels is an attempt to reverse underfunding and emphasizes climate change as a priority, said Norman Dicks (Democrat, Washington), chair of the

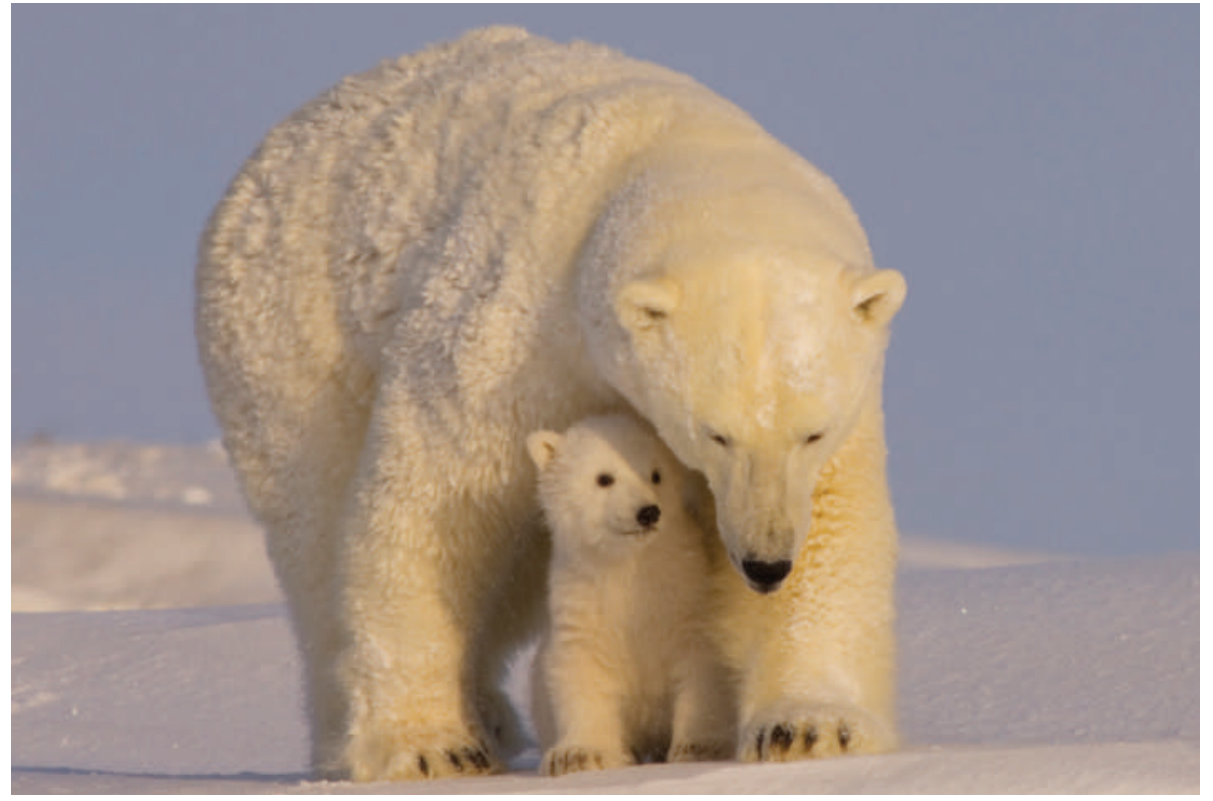

A recovery plan must be drawn up for the polar bear, which was last year listed as 'threatened'.

House Subcommittee on Interior, Environment, and Related Agencies, in a statement.

The FWS has faced a "chronic" lack of science resources ever since its biology research programme was moved to a separate Interior agency — the National Biological Survey — in 1993, says Ashe. That became part of the US Geological Survey (USGS) in 1996. Today, the FWS usually has to pay part of the project costs to acquire biological, geographical and water research from the USGS, he says.

Sue Haseltine, associate director for biology at the USGS in Reston, Virginia, agrees that the USGS - considered to be the main research arm for the Interior - doesn't have enough resources to satisfy all of the federal and state agencies it serves. The problem has worsened recently because challenges such as climate change are creating higher-priority research needs, she says: "The urgency has increased."

The USGS has requested its own funding boost in the 2010 budget to help it investigate the effects of climate change on wildlife. $\$ 15$ million of the \$1.1-billion budget it has requested would go towards the new National Climate Change and Wildlife Science Center, a network of research hubs meant to translate global climate data to regional scales and predict effects on habitats and populations.

The agency is also seeking $\$ 5$ million to lend ecological- and population-modelling support to the FWS's proposed landscape conservation cooperatives, and $\$ 4.2$ million to expand its forecasting of changes in Arctic ecosystems.

Ashe says that the FWS is trying to restore some of the scientific credibility that it lost during the last administration. Interior official Julie MacDonald, who oversaw the FWS, resigned in 2007 after an investigation found that she had manipulated scientific conclusions in endangered-species reports and shared internal information outside the agency. The FWS has since decided to revise seven of MacDonald's Endangered Species Act decisions.

Jeff Ruch, executive director of Public Employees for Environmental Responsibility in Washington DC, says that the critical question is whether the agency will pay attention to its scientific findings. "There's no absence of science it could use now," he says. But if it's not funnelled into management decisions, he says, "it's \$20 million window dressing".

The FWS may soon get new leadership from a 30-year veteran: Sam Hamilton, who currently oversees its southeast region, has been nominated to head the agency. His nomination must be confirmed by the Senate.

Roberta Kwok 